Int. J. Electrochem. Sci., 13 (2018) 1051 - 1061

International Journal of

ELECTROCHEMICAL

SCIENCE

www.electrochemsci.org

\title{
An Electrochemical DNA-Hybridization Assay for Acinetobacter baumannii Detection
}

Yanping Wang, Haiwu He, Haizhen Liu, Cui Feng and Zhongji Yao*

The second affiliated hospital of Hainan medical school, Haikou City, Hainan Province, 570000, P.R.China

*E-mail: zhongjiyao@163.com

doi: $10.20964 / 2018.01 .72$

Received: 27 September 2017 / Accepted: 19 November 2017 / Published: 16 December 2017

The present paper reported the analysis of the Acinetobacter baumannii using an electrochemical biosensor fabricated based on a gold electrode $(\mathrm{AuE})$ with the electroactive label of $\beta$-cyclodextrin $(\beta$ $\mathrm{CD})$. Due to the formation of an $\mathrm{Au}-\mathrm{S}$ bond, a thiol decorated single-stranded DNA probe was covalently immobilized onto the electrode surface. For the working mechanism of differential pulse voltammetry (DPV) on the DNA hybridization, the electrochemical signals of the $\beta$-CD binding reduction to the double-stranded DNA (ds-DNA) were recorded. Moreover, the as-prepared biosensor has the potential of being used for the analysis of Acinetobacter baumannii in excrement specimens.

Keywords: DNA; Acinetobacter baumannii; Gold electrode; $\beta$-cyclodextrin; Differential pulse voltammetry

\section{$\underline{\text { FULL TEXT }}$}

(C) 2018 The Authors. Published by ESG (www.electrochemsci.org). This article is an open access article distributed under the terms and conditions of the Creative Commons Attribution license (http://creativecommons.org/licenses/by/4.0/). 